\title{
Alternate-day Treatment with Crizotinib for Drug-induced Esophagitis and Liver Damage in a Patient with EML4-ALK Fusion Gene-positive Lung Adenocarcinoma
}

\author{
Yoko Tsukita ${ }^{1}$, Tatsuro Fukuhara ${ }^{1}$, Maki Kobayashi ${ }^{1}$, Mami Morita ${ }^{1}$, Aya Suzuki ${ }^{1}$, \\ Kana Watanabe ${ }^{1}$, Tetsuya Noguchi ${ }^{2}$, Yasuko Kurata ${ }^{3}$, Manabu Suno ${ }^{4}$ and Makoto Maemondo ${ }^{1}$
}

\begin{abstract}
A 44-year-old woman who was diagnosed with anaplastic lymphoma kinase-positive lung adenocarcinoma developed brain metastases, multiple spinal metastases and meningeal dissemination. Crizotinib was administered after the failure of first-line chemotherapy. Esophagitis and liver damage were induced by the twicedaily administration of crizotinib at $250 \mathrm{mg}$ and $200 \mathrm{mg}$, respectively. The alternate-day administration of crizotinib (250 mg, twice daily) was able to control disease progression without any adverse effects for several months. We evaluated the relationship between the serum concentration of crizotinib and the development of esophagitis and liver damage. The alternate-day administration of crizotinib is one of the strategies for managing the severe toxicity of crizotinib.
\end{abstract}

Key words: non-small-cell lung cancer, crizotinib, ALK rearrangement, drug-induced esophagitis, alternateday administration

(Intern Med 54: 3185-3188, 2015)

(DOI: 10.2169/internalmedicine.54.4996)

\section{Introduction}

Crizotinib is an oral tyrosine kinase inhibitor (TKI) that blocks the signals from anaplastic lymphoma kinase (ALK), mesenchymal-epithelial transition (MET), and ROS1 (1-3). ALK gene rearrangements, including the rearrangement of the echinoderm microtubule-associated protein-like 4 (EML 4)-ALK fusion gene, are observed in approximately $2-5 \%$ of non-small-cell lung cancer (NSCLC) patients $(4,5)$. Several studies have shown the efficacy of crizotinib to be similar to that of epidermal growth factor receptor TKI (EGFR-TKI) with regard to progression free survival and response rate $(6,7)$. The major adverse effects of crizotinib are vision disorder, diarrhea, nausea, and vomiting. In addition, several reports have demonstrated that severe esophagitis may be induced by crizotinib (8-13). Here, we report a case of recurrent esophagitis induced by crizotinib that was successfully managed by the alternate-day administration of crizotinib.

\section{Case Report}

A 44-year-old woman who was diagnosed with lung adenocarcinoma underwent a left lower lobectomy in February 2003 (pT1N2M0 stage IIIA). In July 2011, a brain tumor was resected from the left temporal lobe and pathologically confirmed as a metastatic tumor from lung cancer. EML4ALK gene-fusion was detected in the metastatic brain tumor by an immunohistochemical analysis and fluorescent in situ hybridization. It was also subsequently detected in the surgical specimen of the primary lung cancer by an immunohistochemical analysis. No other recurrent lesions were found, thus she was indicated for observation without additional treatment. In July 2012, multiple brain metastases and meningeal dissemination appeared. The brain metastases progressed despite 3 cycles of cisplatin and pemetrexed,

\footnotetext{
${ }^{1}$ Department of Respiratory Medicine, Miyagi Cancer Center, Japan, ${ }^{2}$ Department of Gastrointestinal Medicine, Miyagi Cancer Center, Japan, ${ }^{3}$ Department of Pharmacy, Okayama University Hospital, Japan and ${ }^{4}$ Center for the Development of Medical and Health Care Education, Okayama University, Japan

Received for publication January 21, 2015; Accepted for publication April 14, 2015

Correspondence to Dr. Makoto Maemondo, maemondo-ma693@aioros.ocn.ne.jp
} 


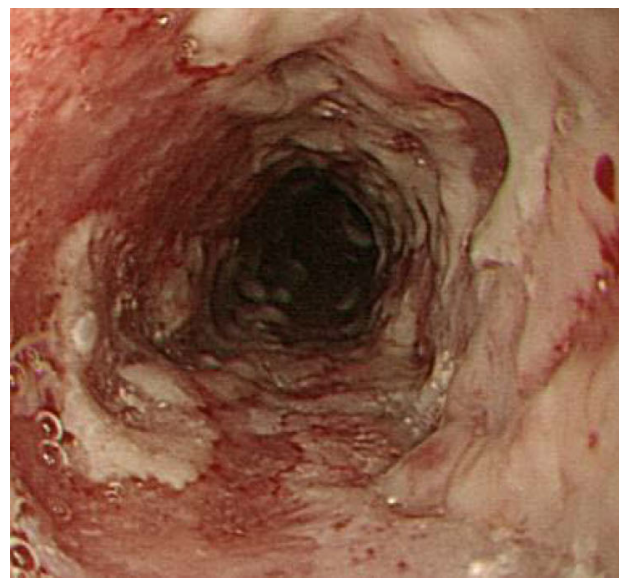

A

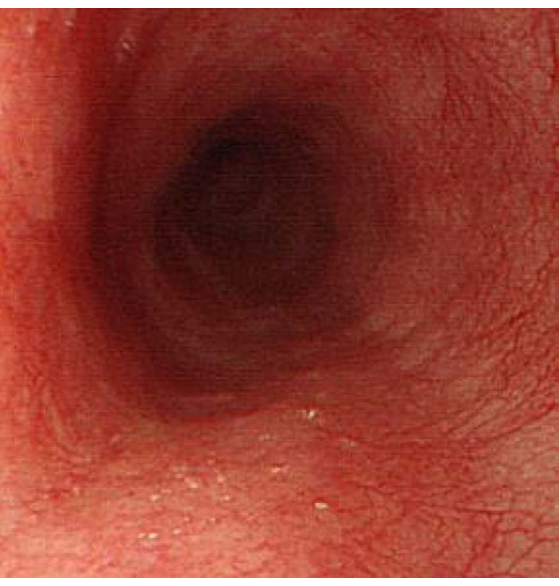

B

Figure 1. A: Esophagogastroduodenoscopy revealed erosive lesions with white coat and vesicles in the middle and lower thoracic part of the esophagus. B: Esophagitis disappeared ten days after crizotinib discontinuation.

Table. Serum Concentration of Crizotinib.

\begin{tabular}{|c|c|c|c|c|c|c|}
\hline & $\begin{array}{c}\text { Dose } \\
\text { (mg/day) }\end{array}$ & $\begin{array}{l}\text { Dosing } \\
\text { interval }\end{array}$ & $\begin{array}{l}\text { Dosing } \\
\text { period } \\
\text { (day) }\end{array}$ & $\begin{array}{l}\text { Administration day } \\
\text { or } \\
\text { non administration day }\end{array}$ & $\begin{array}{l}\text { Before or after } \\
\text { administration }\end{array}$ & $\begin{array}{l}\text { Concentration } \\
\quad(\mathrm{ng} / \mathrm{mL})\end{array}$ \\
\hline$* 1$ & 500 & daily & 7 & administration day & after & 468 (peak) \\
\hline *2 & 400 & daily & 15 & administration day & before & 212 (trough) \\
\hline$* 3$ & 500 & alternate day & 7 & administration day & before & 17.5 (trough) \\
\hline$* 4$ & 500 & alternate day & 29 & administration day & before & 52.8 (trough) \\
\hline$* 1$ & Severe es & phagitis devel & & & & \\
\hline *2 & Liver dam & age appeared. & & & & \\
\hline
\end{tabular}

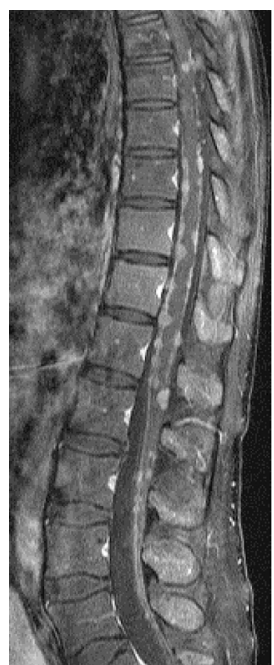

A

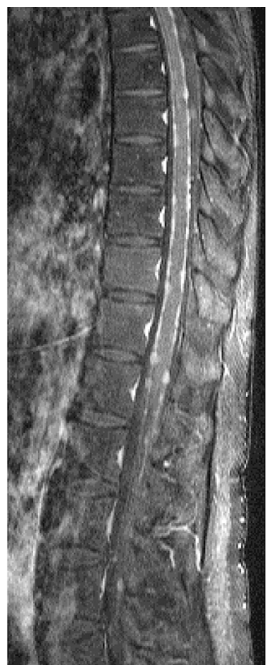

B

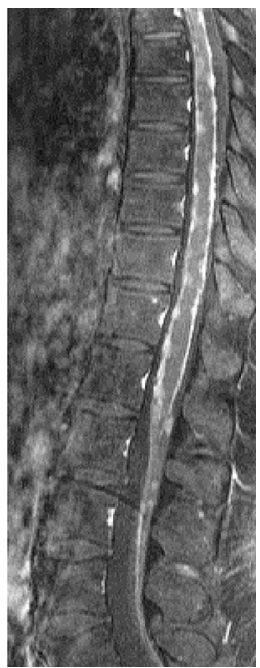

C
Figure 2. A: Seven months after discontinuation of the first crizotinib treatment, MRI revealed multiple spinal nodules and enhancement of the meninges. B: Two months after alternate-day administration of crizotinib at $250 \mathrm{mg}$ daily, MRI showed shrinkage of the spinal nodules. C: Five months after alternate-day administration of crizotinb, MRI demonstrated regrowth of the spinal nodules. thus she underwent whole brain radiation therapy. A secondline treatment with crizotinib (250 mg, twice daily) was started. Dysphasia and retrosternal pain developed rapidly (within one week). Esophagogastroduodenoscopy (EGD) revealed severe esophagitis in the middle and lower thoracic parts of the esophagus (Fig. 1A). The patient's serum concentration of crizotinib was $468 \mathrm{ng} / \mathrm{mL}$ at the onset of esophagitis (Table). The administration of crizotinib was discontinued, and she recovered from the symptoms after ten days. The improvement of the esophagitis was confirmed by EGD (Fig. 1B). The administration of crizotinib was resumed at a reduced dose ( $200 \mathrm{mg}$, twice daily), but 15 days later there was a grade 3 elevation in her alanine aminotransferase (ALT) level. The patient's serum concentration of crizotinib was $212 \mathrm{ng} / \mathrm{mL}$ (Table). The administration of crizotinib was discontinued and she was discharged after recovery from crizotinib-induced hepatic toxicity.

Seven months after discharge, she developed lower extremity weakness and dysuria. Magnetic resonance imaging (MRI) revealed the progression of multiple spinal metastases and meningeal dissemination (Fig. 2A). The reinitiation crizotinib treatment was considered necessary due to the lack of other treatment options. The alternate-day administration of crizotinib (200 mg, once daily) was started. The alternateday treatment was continued but the dose was sequentially increased to $250 \mathrm{mg}$, twice daily. The alternate-day treat- 
ment did not induce any signs of toxicity such as esophagitis or liver dysfunction. MRI showed the shrinkage of the spinal metastases two months after the initiation of the alternate-day administration of crizotinib (250 mg, twice daily) (Fig. 2B). Five months after the initiation of alternateday administration, the regrowth of the spinal metastases was observed by MRI (Fig. 2C). The crizotinib dose was increased to $250 \mathrm{mg}$, twice daily. Fourteen days later, esophagitis re-developed and the treatment was stopped. EGD performed seven days after the discontinuation of crizotinib treatment, confirmed the improvement of esophagitis. It was difficult to treat this patient with cytotoxic agents due to her poor performance status. At the time, next generation ALK inhibitors were not yet commercially available. The alternate-day treatment of crizotinib (250 mg, twice daily) was expected to delay the progression of meningitis. The serum concentration of crizotinib reached $17.5 \mathrm{ng} / \mathrm{mL}$ at seven days after the re-initiation of treatment and $52.8 \mathrm{ng} / \mathrm{mL}$ after 29 days (Table). Crizotinib treatment was continued for 3 months without any adverse effects until the patient's neurological symptoms worsened.

\section{Discussion}

In phase I and II trials of crizotinib, three cases of esophagitis and one case of esophageal ulceration were reported among 255 patients (14). To our knowledge, there are six case reports of crizotinib-induced esophagitis (8-13). The mechanism of crizotinib-induced esophagitis is not clear. In our case, esophagitis was induced by administration of crzotinib at $250 \mathrm{mg}$, twice daily, but not by $200 \mathrm{mg}$, twice daily or the alternate-day administration at $250 \mathrm{mg}$, twice daily. The patient's serum concentration of crizotinib $(468 \mathrm{ng} / \mathrm{mL})$ at the first presentation of esophagitis was not higher than the serum concentrations observed in the clinical trials (15). The patient's esophagitis may be have been related not only to the serum concentration of crizotinib, but also to other factors, including drug sensitivity. We decided to administer crizotinib on alternate days after the reduction of the daily dose failed due to toxicity. Thus far, there are no published data that support the alternate-day administration of crizotinib. However, the clinical benefit of the alternate-day administration of gefitinib, an EGFR-TKI, has been reported $(16,17)$. Satoh et al. suggested that the intermittent administration of gefitinib may be clinically equivalent to standard-dose gefitinib for cases of NSCLC with sensitive EGFR mutations in terms of progression free survival and overall survival (16). In our case, although the trough level of crizotinib was lower than the effective serum concentration, this dosing method was able to control disease progression for five months and improved the patient's performance status with manageable side effects. This alternate-day dosing method may be a therapeutic option when unmanageable toxicity is induced by crizotinib. More cases are needed to assess the efficacy of the alternate-day administration of crizotinib.
We reported a case of recurrent esophagitis induced by the administration of crizotinib (250 mg, twice daily). We could manage the side effects and control the progression of disease by the alternate-day administration of crizotinib.

\section{Author's disclosure of potential Conflicts of Interest (COI).}

Makoto Maemondo: Honoraria, Pfizer Japan and Chugai Pharmaceutical; Research funding, Chugai Pharmaceutical.

\section{References}

1. Kwak EL, Bang YJ, Camidge DR, et al. Anaplastic lymphoma kinase inhibition in non-small-cell lung cancer. $\mathrm{N}$ Engl J Med 363: 1693-1703, 2010.

2. Ou SH, Kwak EL, Siwak-Tapp C, et al. Activity of crizotinib (PF 02341066), a dual mesenchymal-epithelial transition (MET) and anaplastic lymphoma kinase (ALK) inhibitor, in a non-small cell lung cancer patient with de novo MET amplification. J Thorac Oncol 6: 942-946, 2011.

3. Bergethon K, Shaw AT, Ou SH, et al. ROS1 rearrangements define a unique molecular class of lung cancers. J Clin Oncol 30: 863$870,2012$.

4. Takahashi T, Sonobe M, Kobayashi M, et al. Clinicopathologic features of non-small-cell lung cancer with $E M L_{4}-A L K$ fusion gene. Ann Surg Oncol 17: 889-897, 2010.

5. Shaw AT, Kim DW, Nakagawa K, et al. Crizotinib versus chemotherapy in advanced ALK-positive lung cancer. N Engl J Med 368: 2385-2394, 2013.

6. Maemondo M, Inoue A, Kobayashi $\mathrm{K}$, et al. Gefitinib or chemotherapy for non-small-cell lung cancer with mutated EGFR. N Engl J Med 362: 2380-2388, 2010.

7. Solomon BJ, Mok T, Kim DW, et al. First-line crizotinib versus chemotherapy in ALK-positive lung cancer. N Engl J Med 371: 2167-2177, 2014.

8. Yamazoe M, Saijo H, Ishikawa T, Kobayashi T, Takahashi R. A case of crizotinib-induced esophagitis in a patient with EML4$A L K$-positive lung adenocarcinoma. Haigan (Jpn J Lung Cancer) 53: 840-845, 2013 (in Japanese, Abstract in English).

9. Park J, Yoshida K, Kondo C, et al. Crizotinib-induced esophageal ulceration: a novel adverse event of crizotinib. Lung Cancer 81: 495-496, 2013.

10. Srivastava N, VanderLaan PA, Kelly CP, Costa DB. Esophagitis: a novel adverse event of crizotinib in a patient with ALK-positive non-small-cell lung cancer. J Thorac Oncol 8: e23-e24, 2013.

11. Takakuwa O, Oguri T, Yokoyama M, et al. Esophagitis resulting from treatment with crizotinib for anaplastic lymphoma kinase rearrangement-positive lung adenocarcinoma: a case report. Mol Clin Oncol 2: 121-123, 2014.

12. Abdel Jalil A, Craig J, Bajaj R, Spurling T. Sever ulcerative esophagitis induced by crizotinib therapy. ACG Case Rep J 1: 8284, 2014.

13. Hirai N, Sasaki T, Yamamoto Y, Ohsaki Y. Crizotinib-induced esophagitis developing during the course of treatment for adenocarcinoma of the lungs associated with the EML4/ALK fusion gene. Haigan (Jpn J Lung Cancer) 54: 68-72, 2014 (in Japanese, Abstract in English).

14. Pfizer: Crizotinib adverse events reported from clinical trials (PROFILE 1001 study and PROFILE 1005 study) [Intertet]. [cited 2014 Oct. 8]. Available from: https://pfizerpro.jp/download.php?ke $\mathrm{y}=\mathrm{Cad} 1 \mathrm{UdxtexCWBqUNzxhlMg==}$

15. Nosaka S, Yamaguchi S, Nagasawa T, Tahara M. Pharmacology profile of crizotinib (Xalkori ${ }^{\mathbb{R}}$ Capsules) and clinical findings on this drug. Nippon Yakurigaku Zasshi (Folia Pharmacol Jpn) 141: 106-113, 2013 (in Japanese). 
Intern Med 54: 3185-3188, 2015 DOI: 10.2169/internalmedicine.54.4996

16. Satoh $\mathrm{H}$, Inoue $\mathrm{A}$, Kobayashi $\mathrm{K}$, et al. Low-dose gefitinib treatment for patients with advanced non-small cell lung cancer harboring sensitive epidermal growth factor receptor mutations. J Thorac Oncol 6: 1413-1417, 2011.
17. Fujita T, Teramoto K, Ozaki Y, et al. Retrospective study of alternate-day administration of gefitinib. Haigan (Jpn J Lung Cancer) 47: 9-12, 2007 (in Japanese, Abstract in English).

(C) 2015 The Japanese Society of Internal Medicine http://www.naika.or.jp/imonline/index.html 